\title{
CORRIGENDUM
}

\section{Antonis Anastasopoulos}

\section{ANTONIS ANASTASOPOULOS AND ELIAS \\ KOLOVOS, EDS., Ottoman Rule and the Balkans, 1760-1850: Conflict, Transformation, Adaptation (REVIEWED BY İPEK K. YOSMAOĞLU)}

(Volume 41, Number 3, 2009; Pages 494-96. doi:10.1017/S0020743809091259)

The price of $\$ 63.00$ was erroneously assigned to this book, which is not commercially available. The Department of History and Archaeology of the University of Crete has distributed it free of charge to academic libraries and individual scholars. Please also note that the book is a paperback, not cloth.

\footnotetext{
Antonis Anastasopoulos is an Assistant Professor of Ottoman History, Department of History and Archaeology, University of Crete, Greece; e-mail: anastasopoulos@phl.uoc.gr

(C) Cambridge University Press 2010 0020-7438/10 \$15.00
} 